\title{
The Research of Enterprise Reverse Logistics Outsourcing Risk and Countermeasures
}

\author{
$\mathrm{Na} \mathrm{Li}^{1, \text { a }}$, Jiahua Zhang ${ }^{2, \mathrm{~b}}$ and Hong Wang ${ }^{3, \mathrm{c}}$ \\ ${ }^{1}$ Qingdao Huanghai University, Qingdao, Shandong, China \\ 2 Datang huangdao Power Generation Co.,Ltd, Qingdao, Shandong, \\ China \\ ${ }^{3}$ Qingdao Huanghai University, Qingdao, Shandong, China

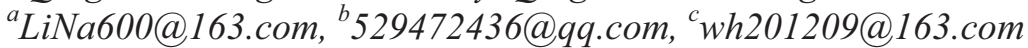

\begin{abstract}
The vigorous development of logistics industry is to adapt to the improvement of economic level. And many enterprises for the reverse logistics choose the form of outsourcing. This is part of the business decisions, plays an important role to the development of oneself. However, the enterprise reverse logistics outsourcing also exists certain risk. In this paper, from a strategic, management, cooperation, terminal and so on four aspects has carried on the corresponding summary and provides the solving strategies.

Keywords: Reverse logistics, Outsourcing, Risk.
\end{abstract}

\section{Introduction}

Rapid economic growth has brought the vigorous development of the logistics industry. However, today many enterprises in order to realize the sustainable development of economy and improve their competitiveness, have made a certain investment in the reverse logistics. Subject to technical experience, personnel and financial resources and other factors, most companies tend to give up proprietary of reverse logistics and outsource as a whole. So they can save more time, manpower and energy and then develop the company's core business. At the same time improve the operation efficiency of reverse logistics to meet customer demand on the whole. And retain more customers and enhance their 
competitiveness. However, the reverse logistics outsourcing also has a certain risk, and it also has brought many new thinking.

Reverse logistics is a kind of logistics activity, but it is different from traditional materials operation or supply. Reverse logistics for material substitution, products returned or maintenance, remanufacturing activities, returns related raw materials, finished or semi-finished products from client to enterprise or sales end[1]. The process of reverse logistics operation includes the flow of information, capital, etc. Therefore, to improve customer satisfaction degree and save enterprise operation resources plays an important role. Operation steps of the reverse logistics and traditional logistics have in common. But because of its dispersion, tardy, complexity and variability, enterprises in reverse logistics outsourcing at the same time aiming at the risk and problems in the process of its management and operation should be given more attention.

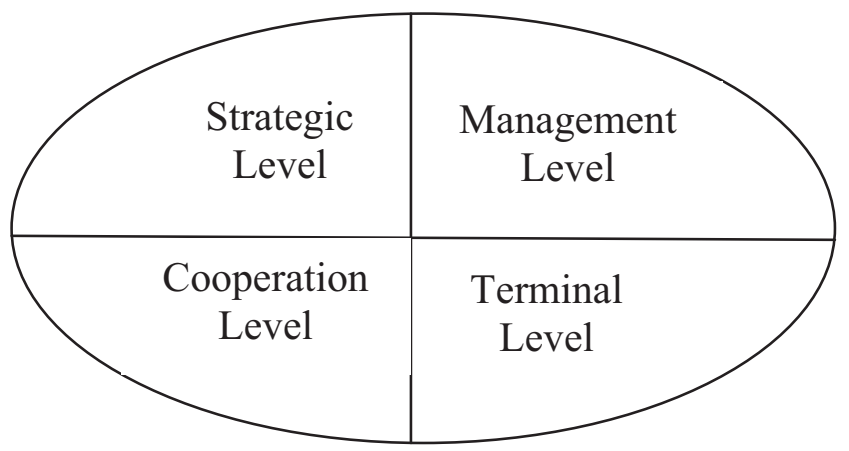

Fig. 1 Reverse logistics outsourcing risk

Strategic Level. Enterprise reverse logistics outsourcing occupies an important position in the company's strategy[2]. On the one hand, the enterprise will whether choose reverse logistics outsourcing. Different enterprises according to their own comprehensive considerations of personnel, financial resources, etc need to make the suitable for their own decisions whether for reverse logistics outsourcing. It plays an important role to the enterprise's own development. On the other hand is the enterprise to the choice of logistics company. Logistics company's service quality is related to customer satisfaction to the enterprise. And its running cost is related to enterprise's investment. All these have a direct relationship to the competitiveness of the enterprises.

Management Level. Both sides of the outsourcing often have conflict in management mode, cultural differences, interests, economic and environmental contradictions coordination way, etc[3]. In personnel management, first, the reverse logistics outsourcing will lead to their own original of the business needs of the logistics staff weakened. If related leaders don't consider the staff's mood, it will affect the normal play not corresponding department. Second, after reverse outsourcing, its executive is logistics company's employees. The corresponding enterprise has no administrative privileges. This is disadvantage for the solution of 
the problem in the work. In the aspect of financial management, financial risk refers to the enterprises in the process of using the third party reverse logistics cost need to pay a lot of risks[4]. Enterprises are profit as the goal. The economic cost of investment and the strength of the enterprise have a direct relationship. And in the process of reverse logistics outsourcing has many details. In the storage, transportation, information processing and so on many levels all have the corresponding implicit costs. Therefore, in the reverse logistics outsourcing, it should fully consider various capital investments.

Cooperation Level. Due to the logistics service providers directly dealing with customers, will reduce the enterprise the opportunity to direct contact with customers. This to a certain extent weakened on the relationship between the client and the customer, resulting in customer relationship management risk[5]. It is cooperation relationship between enterprises and logistics companies. However, the same logistics company may face many of the same type enterprise. It will also lead to many problems. Enterprise related strategy, for example, is more likely to be working with logistics companies directly or indirectly disclosed. In addition, logistics service supplier quality problems may be as the change of season and other factors and cause a corresponding wave. And it will affect the corporate image. Moreover, return of goods entry and statistical information may not be timely communication and it will produce certain problems.

Terminal Level. Enterprises are not directly involved in the docking with the customer. It will inevitably lead to the corresponding problems. On the one hand is the customer feedback information and enterprise's message can't be timely and effective communication. It will cause the customer to enterprise's misunderstanding. And if the problem that the customer feedback is not timely solve, the progress of enterprise growth has bad influence. On the other hand is the quality of service customers feel is not controlled by the enterprise. Logistics is related to the supplier's personnel directly communicate with the customer. The quality of service plays an important role in the image of the enterprise. However it is not subject to the restriction and supervision over enterprises. Therefore, it is difficult to meet customer demand in certain level. Furthermore, it leads to customer dissatisfaction and affects the company's image.

\section{Risk prevention}

To Make the Right Decisions. When companies are outsourcing reverse logistics, the enterprise should accord to their own needs. Combination of personnel, financial factors such as comprehensive consideration make the best decisions. For example, enterprises may grasp core technology, key customers and other key business. And the rest of the business outsourcing, on the one hand, reduces the burden of logistics company. On the other hand, improve the customer satisfaction, at the same time avoid the internal strategy of information disclosure. In addition, when select logistics service providers, should conduct comprehensive considerations. Fully consider and try to compare the price, quality of service, 
industry experience. Then choose the most suitable, and formulate detailed cooperation plan, constraint on both sides of the behavior of moral and legal.

In the macro environment investigation analysis, we focus on collecting analysis is closely related to the enterprise survival and development of the national and local political laws, regulations, the development of the local economic environment, transportation, the distribution of population, social and cultural aspects of information. In the competitive environment investigation analysis, enterprises should collect and analyze the competition situation and development strategy, grasp the needs of customers change, focus on dynamic replacement and new entrants and the characteristics of the third party logistics market. When making strategic investigation and analysis to consider the factors and the relationship between the enterprises to carry out the right after a full range of internal and external environmental analysis, you can work out the overall development of the enterprise strategy, Determine whether or not the core business or key business then may according to the theory of cost advantage and risk theory to decide whether outsourcing, then can for effective supervision, and promote service providers

Perfect the Management System. The first is for the internal management. On the one hand, is for the internal personnel management. Enterprises should pay close attention to the condition that internal logistics personnel, and appropriate measures such as encouraging. To face the challenges of the logistics outsourcing to the corresponding positive response, improve the work efficiency[6]. On the other hand, is the aspect of financial management. In view of the budget should be detailed planning. In view of the logistics and the cost of the product should be strict controlled to implement the use of funds. The second is for the management of the logistics service. We should establish perfect logistics service supervision system on the service quality of the logistics supplier of supervision and evaluation. At the same time strive to keep the symmetry of information to make the valuables information can be delivered to get timely. The information of customer feedback can get complete message.

The Collaborative Communication Mechanism. The first is to strengthen the supervision of the third party logistics company and set up reverse logistics goods tracking information system. To track return items in each recovery link and to build a returns management information system. This can reduce the intact items missing or valuables in danger of missing parts. The second is to establish strategic partnership with the third party reverse logistics enterprises and put it into the part of the supply chain. For enterprises, cooperation with the third party reverse logistics can not only reduce the inventory holding cost and logistics service management cost and comprehensive enterprise logistics cost, but also can make the enterprise to focus on the core competitiveness, enhance customer satisfaction, improve enterprise flexibility and many other interests. If the cooperation goes well, it can achieve the goal of win-win cooperation. Therefore, to establish strategic relations with the third party reverse logistics enterprises rather than a narrow trading relationship. Let the third party reverse logistics enterprises 
understand the production requirements. And write clearly on the contract enterprise required reverse logistics services, not vague or general.

After the outsourcing of logistics activities of the enterprise, does not mean that the outsourcing of logistics activities can be ignored, on the contrary must be regularly or not regularly for performance evaluation of logistics providers, to ensure the quality and cost of outsourcing logistics sophistication and rationality. In order to prevent risks, it is necessary for the third party logistics providers set up from the process to the results of the inspection system, and mechanism must be established to ensure that the company can keep close touch with the development of the logistics market, the industry, make the enterprise logistics service quality and the cost to maintain advanced nature and rationality. Logistics outsourcing party shall establish the evaluation index set based on the actual performance evaluation mechanism of the third party logistics operation. At the same time it should be maneuver-

ability, and can accurately reflect the operation of relationship between customer and logistics enterprise, at the time of operation of the third party logistics market situation. For logistics supplier performance evaluation can be made by outsourcing logistics enterprises to form the panel of judges or retain independent of external personnel to monitor the performance of logistics service providers, in order to find problems in a timely manner to correct, proper treatment can be used according to the terms of the contract. Through performance appraisal, is clear about the direction of the next step of work improvement, to provide convenient conditions for each other cooperation. So performance management may play a role in customer business and logistics service providers.

Establish the Risk Management Department. Enterprises should strengthen the logistics outsourcing risk management specific work. The basic process of enterprise logistics outsourcing risk management should be divided into risk identification, risk measurement, risk management, risk management decision-making plan execution, risk management evaluation after five stages of dynamic. Due to longitudinal logistics outsourcing risk management throughout the course of the logistics outsourcing activities as well as horizontal and enterprise departments work closely linked. So it is necessary to set up special logistics outsourcing risk management manager. Logistics outsourcing risk management should be like the logistics purchasing managers working for the success of enterprise logistics activities, and enjoy the corresponding position in liability.

Cooperation with the third party logistics providers is a long-term process, need to pay attention to relationship management, continue to consolidate cooperation means interest is coexistence of supply and demand. Good cooperation can benefit both sides of supply and demand, and the poor performance of either party would damage the interests of both parties. So the supply and demand both sides should establish the win-win idea, make both parties cooperation development in healthy direction. Before cooperation, logistics outsourcing contract should be signed to make a clear division of responsibility on both sides. At the same time, joint logistics solutions make the outsourcing 
business and logistics service to be better fusion together. Both top head of regular contact, exchange views, exchange information, establish a highly reliable and mutual support of close relations of cooperation. Logistics outsourcing enterprises can also organize the team to work with the third party logistics provider, and jointly manage all issues related to the contract or agreement. When finding the poor performance and their own enterprise logistics providers in the cooperation and support is insufficient, enterprise can modify it in time. Both sides continue to strengthen exchanges in cooperation, jointly promote the development of the relations of cooperation.

\section{Conclusions}

To sum up, when the enterprise is in the reverse logistics outsourcing, there is a certain risk. This requires enterprise combined with their situation to comprehensive considerations to make the choice to improve their own competitiveness and to minimize the risks.

\section{Acknowledgments:}

Supported by Shandong Youth Quality Education Project (Project Number: 16SZJ038)

Colleges and Universities Humanities and Social Science Research Project in Shandong Province ( Project Number: J15WB70)

\section{References:}

[1] Y. J. Liang, Talk about the development of the contemporary enterprise reverse logistics[J], Foreign economic and trade practice, 2011,01:86-88(In Chinese)

[2] J. Q. Zhong, Enterprise reverse logistics mode and countermeasures[J], Science and technology management research, 2011,13:102-105(In Chinese)

[3] M. Laura and S. Joseph, Strategic analysis of logistics and supply chain management systems using the analytical network process[J].Transpn Res. E (Logistics and Transpn Rev.) 1998,34,(3): 201-215

[4] Y. Zhang, Risk Identification of Reverse Logistics Outsourcing, logistics engineering and management[J], 2011,9:17-18(In Chinese)

[5] J. B. Hu, Analysis of logistics outsourcing risk and countermeasures, The operation and management, 2012:04:34-36(In Chinese)

[6] Y. N. Jiang and S. C. Hao, The interests of the development of reverse logistics related main bodies and game[J], Special zone economy, 2012,01:283-285(In Chinese) 